SAKAI SAMBAYAN — Jurnal Pengabdian kepada Masyarakat

\title{
PENINGKATAN EKONOMIS LIMBAH PRODUKSI JAMUR MERANG MENJADI BRIKET SEBAGAI SUMBER ENERGI ALTERNATIF DI DESA BAYUR KECAMATAN RAJABASA
}

\author{
Yuli Darni $^{i^{*}}$, Herti Utami ${ }^{2}$, Darmansyah ${ }^{3}$, Lia Lismeri ${ }^{4}$ dan Nandi Haerudin ${ }^{5}$ \\ 1,2.3.4 Jurusan Teknik Kimia Universitas Lampung, Bandar Lampung \\ ${ }^{5}$ Jurusan Teknik Geofisika Universitas Lampung, Bandar Lampung \\ Jl. Prof. Sumantri Brojonegoro No.1 Bandar Lampung 35145 \\ Penulis Korespodensi : yuli.darni@eng.unila.ac.id
}

\begin{abstract}
Abstrak
Jamur merang merupakan salah satu jenis jamur yang mulai dikembangkan di Desa Bayur. Mereka membudidayakan jamur merang karena komoditi tersebut laku di pasaran, pemeliharaannya relatif mudah dan murah dengan harga yang cukup menguntungkan. Untuk media jamur merang digunakan tandan kosong kelapa sawit yang merupakan pemanfaatan limbah dari perkebunan kelapa sawit. Setelah beberapa kali panen, media jamur merang diganti dengan media baru. Dari tandan kosong kelapa sawit yang digunakan, akan tersisa media jamur yang menjadi limbah yang menumpuk dan sulit untuk diuraikan karena adanya kandungan selulosa dan lignin dari tandan kosong kelapa sawit. Lama kelamaan limbah ini akan mencemari lingkungan dan mengandung bibit penyakit. Masalah yang dihadapi mitra adalah terkait aspek penyediaan energi dan manajemen pengolahan limbah sisa produksi jamur. Untuk mengatasi permasalahan tersebut, tim pengabdi akan memberikan pelatihan cara pembuatan briket dan mendesain alat pencetak briket arang dari sisa media jamur merang. Pembuatan alat pencetak ini akan memberikan manfaat kemandirian dalam penyediaan energi dan pemanfaatan limbah hasil produksi.

Kegiatan pengabdian ini menggunakan metode yang melibatkan mitra khususnya petani jamur merang dalam kegiatan secara keseluruhan. Luaran kegiatan berupa alat pencetak briket dan peningkatan kemampuan dan pengetahuan mitra. Pengembangan produk briket dapat dimanfaatkan sendiri dan dijual secara komersial. Dengan pelatihan ini kemampuan mitra membuat produk briket dapat mengurangi biaya produksi dan meningkatkan pendapatan mitra.
\end{abstract}

Kata kunci: teknologi tepat guna; pencetak briket; limbah; media jamur merang

\begin{abstract}
The paddy straw mushroom is one type of mushrooms that begin to be developed in the village of Bayur. They cultivate the paddy straw mushroom because the commodity, can make a lot of money in the market, the maintenance are relatively easy and cheap with the price quite beneficial. For the media paddy straw mushroom used the empty bunches of oil palm which it was the utilization of waste from palm oil plantations. After several harvests, the paddy straw mushroom replaced with new media. Of the empty bunches of oil palm used, the rest of the media mushroom that become waste that accumulates and difficult to decomposed because of the cellulose and lignin of the empty bunches of oil palm. Increasingly the waste will pollute and containing bacterium of disease. The problems faced by partner is related to the aspects of the provision of energy and management waste processing the rest of the production of mushroom. To overcome the problems, the team provide training the procedure of making briquette and design an instrument print of briquette from the rest of the media of mushroom. This instrument give an advantages for both in the independence of energy and the utilization of the waste production .

The method of PKM activity involved the partners (the farmers) in the overall of activities. The outer of this main activity are the instrument print of briquette and to increase the ability and knowledge the partner. The product development briquettes can be used own and sold commercially. With this training, the ability of the partner of the making product briquettes can reduce production cost and to raise the income of partner.
\end{abstract}

Keywords: efficient technology; print of briquettes; waste; media the paddy straw mushroom 


\section{Latar Belakang}

Perkembangan budidaya Jamur merang mulai meningkat cukup pesat dibeberapa daerah di Kecamatan Natar Kabupaten Lampung Selatan. Jamur merang merupakan salah satu jenis jamur yang mulai dikembangkan beberapa tahun ini setelah jamur tiram dan jamur kuping kurang memberikan keuntungan yang diharapkan. Lokasi yang dikenal masyarakat sebagai penghasil jamur merang yaitu di Desa Bayur. Lokasi tersebut memiliki produksi hasil pertanian andalan yaitu berupa hasil budidaya jamur merang.

Pembudidaya jamur di Desa Bayur merupakan pembudidaya jamur secara tradisional. Mereka menggunakan kumbung yang dibuat dari kayu dan bambu, kemudian ditutupi dengan terpal plastik transparan. Untuk strelisiasi digunakan pembakaran dengan kayu bakar pada drum yang berisi air. Kayu bakar digunakan karena jika menggunakan gas elpiji akan membutuhkan biaya yang cukup besar. Kayu bakar itu didatangkan dari luar desa. Biasanya dari daerah yang dekat perbukitan, dimana di daerah itu masih banyak lahan untuk menanam pohon.

Pada proses sterilisasi, temperatur kumbung jamur merang dijaga pada kondisi temperatur $70-$ $80{ }^{\circ} \mathrm{C}$ dan dipertahankan hingga sekitar 4-6 jam lamanya selama proses tersebut berlangsung (Maulana dan Setiawan, 2016).Dalam sekali produksi dibutuhkan kayu sebanyak 1/4 mobil pick up untuk satu kumbung. Jika satu pembudidaya seperti Pak Bandi mempunyai 9 kumbung, maka dalam sekali produksi dibutuhkan kayu sebanyak 2,25 mobil. Jika untuk mendapatkan 1 mobil kayu harus ditebang 1 pohon, maka dibutuhkan sekitar 2,25 pohon untuk sekali produksi. Jika dalam setahun 4 kali produksi maka akan ditebang 9 pohon. Ketika waktu yang dibutuhkan untuk menanam pohon dari bibit hingga layak untuk ditebang guna dipakai sebagai sumber energi membutuhkan waktu minial 5 tahun, maka terjadi ketidakseimbangan antara pohon yang ditebang dengan pohon yang ditanam.

Untuk media jamur merang digunakan tandan kosong kelapa sawit (TKKS) atau dikenal juga dengan istilah tankos kelapa sawit. Penggunaan TKKS sebagai media jamur merang merupakan pemanfaatan limbah dari perkebunan kelapa sawit. Selain digunakan sebagai media jamur merang, TKKS ini digunakan juga untuk media tanam jamur tiram putih (Hidayati, dkk., 2015) dan dapat dikonversi menjadi kompos
(Widiastuti dan Tri-panji, 2007; Hayat dan Andayani, 2014). Untuk media jamur dari serbuk gergaji pernah dibuat untuk biogas dengan bantuan fermentasi anaerobik (Mulyadi dkk., 2016). Secara fisik tandan kosong kelapa sawit terdiri dari berbagai macam serat dengan komposisi antara lain sellulosa sekitar 45.95\%; hemisellulosa sekitar 16.49\% dan lignin sekitar 22.84\% (Darnoko dkk., 1993).

Setelah beberapa kali panen, media jamur merang diganti dengan media baru. Untuk pembubidaya jamur di Desa Bayur dibutuhkan 2 ton TKKS untuk media jamur merang. Dari 2 ton TKKS yang digunakan, akan tersisa 1 ton sisa media jamur yang menjadi limbah. Sisa dari media jamur tersebut menumpuk menjadi tumpukan limbah yang sulit untuk diuraikan karena adanya kandungan selulosa dan lignin dari TKKS. Lama kelamaan limbah ini akan mencemari lingkungan dan mengandung bibit penyakit. Sisa media jamur yang dibuang langsung ke lingkungan dapat menimbulkan pencemaran seperti tempat hinggapnya berbagai vektor penyakit, tempat hidup hewan tanah sampai bau. Solusi praktis yang dilakukan pembudidaya jamur adalah dengan membakarnya. Pembakaran TKKS sisa jamur secara manual ini dapat berlangsung 3-5 hari. Jika musim penghujan tiba, maka hal ini akan menjadi kesulitan tersendiri.

Selama ini sisa medium jamur ditumpuk dan dibiarkan sampai kering kemudian dibakar sedikit demi sedikit. Ketika musim hujan tiba, sisa medium jamur merang ini sulit kering dan sulit dibakar, sehingga menjadi limbah yang membusuk dan mengotori lingkungan.

Medium jamur merang berasal dari tandan kosong kelapa sawit (TKKS). Penggunaan TKKS untuk media jamur sebenarnya merupakan salah satu pemanfaatan limbah kelapa sawit dari PTPN 7. Satu Kumbung jamur membutuhkan 2 ton TKKS untuk media jamur dalam satu kali produksi. Dari 2 ton itu dihasilkan limbah sebanyak 1 ton setelah beberapa kali panen.

Paradigma baru hadir dengan memandang limbah sebagai sumber daya yang mempunyai nilai ekonomi dan dapat dimanfaatkan, misalnya untuk energi, kompos, pupuk ataupun untuk bahan baku industri. Pengolahan limbah menjadi bahan bakar menjadi prioritas ditengah menipisnya cadangan bahan bakar fosil dalam bumi Indonesia. Sumber energi fosil atau minyak bumi merupakan energi yang tidak dapat diperbaharui (unrenewable 
energy) dan tidak dapat diperoleh kembali setelah digunakan, maka diperkirakan beberapa tahun ke depan ketersediaan sumber energi tersebut akan habis. Begitu juga bahan bakar dengan menggunakan kayu dari pohon akan membuat lingkungan semakin tandus karena pohon pohon ditebang demi kebutuhan energi masyarakat.

Masalah yang dihadapi mitra adalah bagaimana penanganan sisa media jamur yang menumpuk dan sulit diuraikan sehingga menjadi limbah dan mengatasi kendala jika pasokan kayu segar untuk bahan bakar tersendat (biasanya di musim penghujan). Jika limbah sisa media jamur merang dapat diubah menjadi sumber energi alternative, maka permasalahan lingkungan dan penyediaan energi sedikit teratasi. Pemanfaatan limbah menjadi bahan bakar padat (briket arang) telah dilakukan oleh Awaludin dan Pratama (2016) yang mengolah limbah serbuk kayu menjadi briket. Kemudian Haerudin dan Karyanto (2016) mengubah limbah sekam padi menjadi briket arang sekam.

Untuk mengatasi permasalahan tersebut, tim pengabdi akan memberikan pelatihan cara pembuatan briket dan mendesain alat pencetak briket arang dari TKKS sisa media jamur merang. Pembuatan alat pencetak ini akan memberikan manfaat berupa (1) kemandirian dalam penyediaan energi dan (2) manajemen limbah hasil produksi. Adanya kedua manfaat ini akan mengurangi biaya produksi dan diharapkan meningkatkan keuntungan mitra.

\section{Bahan dan Metoda}

Pengabdian ini dilaksanakan pada September 2019 di Desa Bayur, Lampung Selatan. Untuk alat pencetak briket dan dilengkapi dengan dongkrak serta alat penunjang lainnya didesain dan dibuat di Bengkel alat CV. Subhan Adhi Sentosa di Kemiling, Bandar Lampung.

Metode kegiatan yang akan digunakan dalam kegiatan pengabdian ini adalah metode yang melibatkan masyarakat dalam kegiatan keseluruhan. Pelaksanaan kegiatan ini melalui penyuluhan, pelatihan dan demonstrasi serta evaluasi untuk melihat efektivitas program sehingga program akan tersosialisasi dengan baik. Sasaran penyuluhan, pelatihan dan demonstrasi alat ditujukan pada masyarakat desa khususnya para petani jamur.

\section{Hasil dan Pembahasan}

Tahap pertama, tim melakukan uji coba tentang pembuatan alat pencetak briket sebagai produk yang dapat dimanfaatkan sebagai sumber energi dan dapat dijual secara komersial. Setelah beberapakali mencoba dan dilakukan uji analisis kadar air, kadar abu, kadar karbon dan nilai kalorinya yang ternyata memenuhi standar nilai SNI. Hasil uji analisis dapat dilihat pada Tabel 1. Dari ujicoba tersebut diperoleh cara atau metode yang cukup sederhana dan mudah untuk dipraktekkan dan sebagai materi untuk pelatihan pengembangan produk briket dari limbah media jamur merang.

Pada pelaksanaan pelatihan dan praktek pembuatan briket, tim memilih cara yang sederhana karena memiliki kemudahan untuk dilakukan di sekitar rumah dan prospek sebagai produk komersial. Dalam metode yang dibuat dapat dilakukan orang per orang dengan memanfaatkan limbah TKKS yang bertumpuk sebagai limbah media tanam jamur merang. Produk briket yang dihasilkan dapat dipakai sendiri sebagai sumber bahan bakar dan jika berlebih dapat dijual.

Tabel 1. Hasil Analisis Ujicoba Briket dari Limbah Media Tanam Jamur Merang

\begin{tabular}{|l|l|l|}
\hline Parameter & $\begin{array}{l}\text { SNI No. } \\
1 / 6235 / 2000\end{array}$ & $\begin{array}{l}\text { Hasil uji rata- } \\
\text { rata briket dari } \\
\text { limbah }\end{array}$ \\
\hline Kadar air (\%) & $\leq 8$ & 2,92 \\
\hline Kadar abu (\%) & $\leq 8$ & 3,56 \\
\hline Kadar karbon (\%) & $\geq 77$ & 96,44 \\
\hline $\begin{array}{l}\text { Nilai kalor } \\
\text { (cal/gram) }\end{array}$ & $\geq 5000$ & 5957.2 \\
\hline
\end{tabular}

Metode atau cara untuk pembuatan briket yang pertama adalah tahap pengarangan. Proses pengarangan dilakukan di dalam drum. Bahan diletakkan di dalam drum lalu diberi dedaunan kering yang bertujuan membantu proses pembakaran. Setalah api menyala tutup drum tersebut tapi jangan terlalu rapat agar api tidak padam. Penutupan ini dilakukan agar api tidak terlalu besar dan bahan baku tidak menjadi abu serta tidak terlalu banyak asap yang keluar. Untuk yang berbahan dari limbah media tanam jamur merang selama 1,5 jam. Lalu setelah bahan baku sudah berubah menjadi arang hitam, pembakaran dihentikan dengan cara menutup rapat drum dan menutup celah-celahnya menggunakan tanah agar tidak ada oksigen yang masuk sehingga proses pembakaran dapat terhenti. Pemadaman dengan 
cara ini dilakukan agar kualitas arang dapat terjaga karena apabila dipadamkan dengan cara disiram air dapat menurunkan kualias arang. Proses pemadaman ini dilakukan selama 24 jam sampai bara benar-benar padam.

Tahap berikutnya adalah penggilingan arang. Penggilingan ini masih dilakukan secara manual. Dimana arang yang sudah jadi diletakkan di sebuah wadah dan ditumbuk sampai halus lalu diayak agar didapatkan ukuran serbuk yang sangat halus dan seragam.

Sementara itu perekat disiapkan.Perekat yang digunakan yaitu menggunakan tepung kanji. Dimana tepung kanji ditimbang sebanyak $10 \%$ dari berat bahan baku. Penggunaan tepung kanji harus dalam kadar yang sesuai agar mendapatkan mutu briket dan api yang bagus. Kadar perekat yang terlalu tinggi dapat menurunkan mutu briket arang yang sering menimbulkan banyak asap (Triono, 2006). Kadar perekat umumnya tidak lebih dari $5 \%$. Lalu perekat dicampur dengan air dengan perbandingan konsentrasi perekat dan air 1:2. Proses pembuatannya yaitu dengan mencampurkan tepung kanji dengan air hangat (suhu berkisar antara $60-75^{\circ} \mathrm{C}$ ) lalu diaduk hingga homogen. Lalu adonan perekat dicampur dengan serbuk arang yang sudah diayak.

Arang yang telah diayak kemudian dibuat adonan briket setelah sebelumnya dicampur dengan perekat tepung kanji sebnayak $10 \%$ dari berat bahan baku. Lalu diaduk sampai adonan siap dicetak.

Pencetakan adonan dilakukan ketika adonan briket sudah menggumpal dan adukan telah homogen. Bentuk briket hasil cetakan yaitu berbentuk silinder dengan diameter $2,5 \mathrm{~cm}$ dan tinggi $6 \mathrm{~cm}$. Caranya dengan memasukkan adonan briket kedalam silinder cetakkan kemudian dikempa dengan alat pengepres dengan tekanan besar yang berasal dari dongkrak hingga padat. Lalu pengunci dibuka agar terlepas dari silinder dan cetakkan siap dikeluarkan.

Pengeringan dilakukan dibawah sinar matahari selama 3-4 hari atau bergantung cuaca. Hal ini bertujuan agar kandungan air pada briket sesuai standar SNI yaitu $\leq 8 \%$. Agar ketika briket dinyalakan didapat api yang bagus, cepat menyala dan tidak berasap.

Melalui kegiatan ini telah dihasilkan suatu cara atau metode yang yang mudah dan sederhana dalam pembuatan briket serta para petani jamur dan masyarakat yang mengikuti pelatihan ini mendapatkan pengetahuan yang bermanfaat dan memiliki kemampuan untuk membuat dan mengembangkan produk briket menjadi usaha skala rumah tangga serta berpotensi untuk dikembangkan menjadi usaha yang lebih besar dan bisa dipasarkan untuk konsumsi masyarakat.

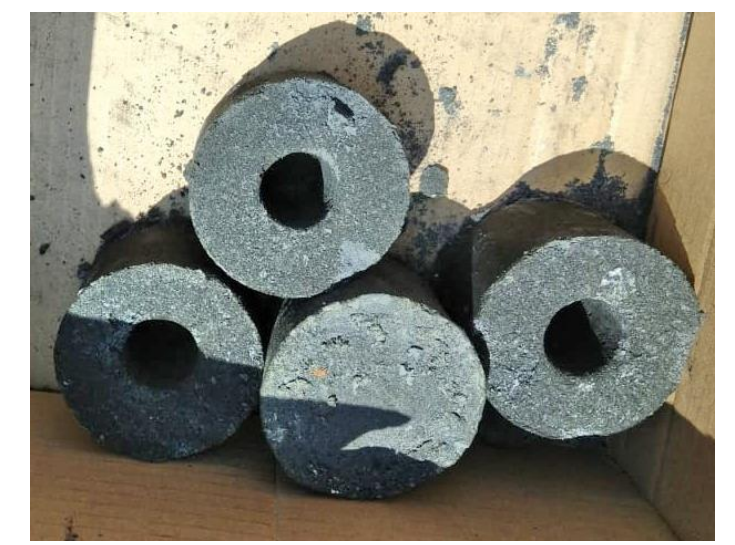

Gambar 1. Produk briket dari limbah media tanam jamur merang

Dengan adanya pelatihan ini kendala yang dihadapi oleh para petani jamur dapat teratasi jika limbah media tanam jamur melimpah, maka dapat dibuat menjadi produk briket. Diharapkan tidak ada lagi limbah media tanam jamur merang yang menumpuk dan produk briket tersebut dapat lebih luas dipasarkan sehingga keuntungan akan meningkat dan tingkat perekonomian para petani jamur tersebut juga meningkat. Terjadi peningkatan pendapatan para petani jamur tersebut dari semula limbah media tanam jamur yang terbuang dan bertumpuk melimpah, kini setelah mendapatkan pengetahuan untuk mengolah lombah media tanam jamur tersebut menjadi produk briket, maka dapat dimanfaatkan sebagai bahan bakar untuk sendiri dan memiliki nilai jual.

Dari hasil evaluasi, dapat dilihat bahwa telah terjadi peningkatan pengetahuan para peserta mengenai pembuatan produk briket di Desa Bayur, Kecamatan Raja Basa. Antusiasme dan animo peserta untuk menerima dan menambah pengetahuan selama kegiatan berlangsung juga mempermudah transfer pengetahuan.

Selain itu dengan pemberian alat pencetak briket kepada kelompok petani jamur ini kendala yang dihadapi oleh para petani jamur dapat teratasi. Diharapkan tidak ada lagi limbah media tanam jamur yang terbuang sebagai limbah dan tingkat perekonomian para petani jamur tersebut meningkat. Terjadi peningkatan pendapatan para 
petani jamur tersebut dari semula limbah media tanam jamur yang terbuang dan melimpah kini setelah ada alat pencetak briket tersebut para petani jamur tersebut dapat mengembangkan limbah media tanam jamur menjadi produk briket yang dapat digunakan sebagai sumber energi untuk produksi jamur merang dan memiliki nilai jual karena produk ini dapat digunakan sebagai bahan bakar alternatif oleh masyarakat secara luas.

Harga jual briket di pasaran untuk. Margin keuntungan yang diperoleh oleh pedagang sayur tersebut adalah sekitar Rp. $30.000,-/ \mathrm{kg}$ briket. Produk briket ini memiliki prospek karena produk ini bahan baku utamanya dari limbah media tanam jamur dan berasal dari bahan yang dapat diperbaharui.

Dengan adanya kegiatan ini memotivasi seluruh anggota kelompok mitra di Desa Bayur, Kecamatan Raja Basa. Alat pencetak briket yang diperoleh mereka dapat digunakan secara bersamasama, dengan pengaturan sesuai ketentuan yang telah disepakati bersama.

\section{Kesimpulan}

Adanya kegiatan pengabdian kepada masyarakat program DIPA BLU Pengabdian Masyarakat Skema Unggulan Unila Tahun Anggaran 2019 untuk Kelompok Petani Jamur Merang di Desa Bayur, Kecamatan Raja Basa, Bandar Lampung ini, permasalahan yang dihadapi mitra dapat segera teratasi dalam rangka meningkatkan pendapatan dan pengetahuan mitra. Dari kegiatan pengabdian ini hasil yang telah dicapai adalah: sebuah alat pencetak briket yang dilengkapi dengan dongkrak, serta kelengkapan untuk pengarangan bahan baku. Selain itu juga terjadi peningkatan kemampuan dan pengetahuan dalam pelatihan pengembangan produk briket dari limbah media tanam jamur merang. Terimplementasinya penerapan pengetahuan yang diperoleh dalam hal pembuatan briket akan meningkatkan pendapatan petani jamur.

\section{Ucapan Terima Kasih}

Tim pelaksana pengabdian mengucapkan terima kasih kepada Universitas Lampung yang telah mendanai program ini melalui program DIPA BLU Pengabdian Kepada Masyarakat Skema Unggulan Unila Tahun Anggaran 2019 dengan No. Kontrak : 3598/UN26.21/PM/2019

\section{Daftar Pustaka}

Awaludin, A. R. dan Pratama, A. W., 2016, Pelatihan Pembuatan Briket Dari Limbah Serbuk Kayu di Desa Balung Kulon Kecamatan Balung Kabupaten Jember. Seminar Hasil Penelitian dan Pengabdian Masyarakat Dana BOPTN Universitas Jember Tahun 2016, ISBN : 978602-14917-3-7.

Darnoko, Z. Poeloengan dan I. Anas, 1993, Pembuatan pupuk organik dari tandan kosong kelapa sawit. Buletin Penelitian Kelapa Sawit, Vol. 2 , p. 89-99.

Haerudin dan Karyanto, 2016, Pelatihan Pembuatan Briket Arang Sekam Untuk Ketahanan Energi Di Gabungan Kelompok Tani Desa Sidodadi Dan Wargomulyo Kabupaten Pringsewu Lampung, Seminar Nasional Pengabdian Kepada Masyarakat 2016 HotelTthe 7th Bandar Lampung 1 Desember 2016.

Hidayati, Hidayat, M. R., dan Asmawit, 2015, Pemanfaatan serat tandan kosong kelapa sawit sebagai media pertumbuhan jamur tiram putih, Jurnal biopropal industri vol. 6 no.2, desember 2015, 73-80.

Maulana, A. dan Setiawan, A., 2016, Uji kesetimbangan kalor proses sterilisasi kumbung jamur merang kapasitas 1.2 ton media tanam menggunakan tungku gasifikasi, TURBO Jurnal Teknik Mesin Univ. Muhammadiyah Metro Vol. 5 No. 2. 2016.

Mulyadi D., Lela M. Y., dan Kusumawati D., 2016, Efektivitas Pemanfaatan Serbuk Gergaji dan Limbah Media Tanam Jamur (Baglog) sebagai Bahan Baku Pembuatan Biogas. Jurnal Kimia VALENSI: Jurnal Penelitian dan Pengembangan Ilmu Kimia, 2(1), Mei 2016, 11-16.

Triono, A. 2006. Karakteristik Briket Arang dari Campuran Serbuk Gergajian Kayu Afrika (Maesopsis emini Engl.) dan Sengon (Paraserianthes falcataria L.) [Skripsi]. Bogor: Departemen Hasil Hutan. Fakultas Pertanian. Institut Pertanian Bogor.

Widiastuti, H. \& Tri-panji, 2007, Pemanfaatan tandan kosong kelapa sawit sisa jamur merang (Volvariella volvacea) (TKSJ) sebagai pupuk organik pada pembibitan kelapa sawit, Jurnal Menara Perkebunan, 2007, 75 (2), 70-79

\section{Dokumentasi Kegiatan}




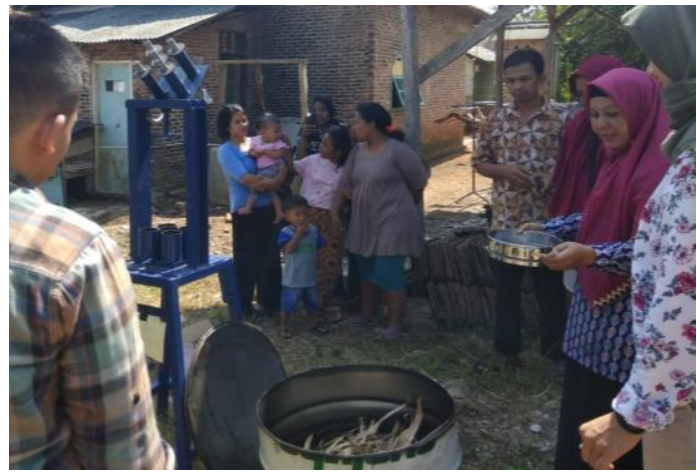

Tim Pelaksana Pengabdian menjelaskan proses pembuatan briket

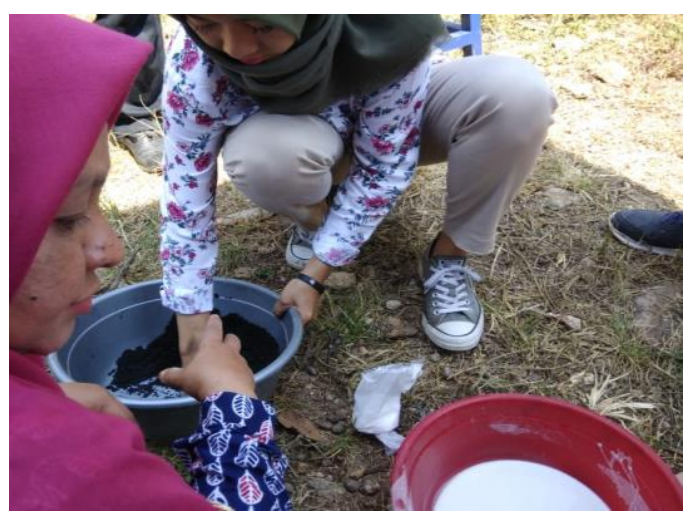

Praktek membuat briket

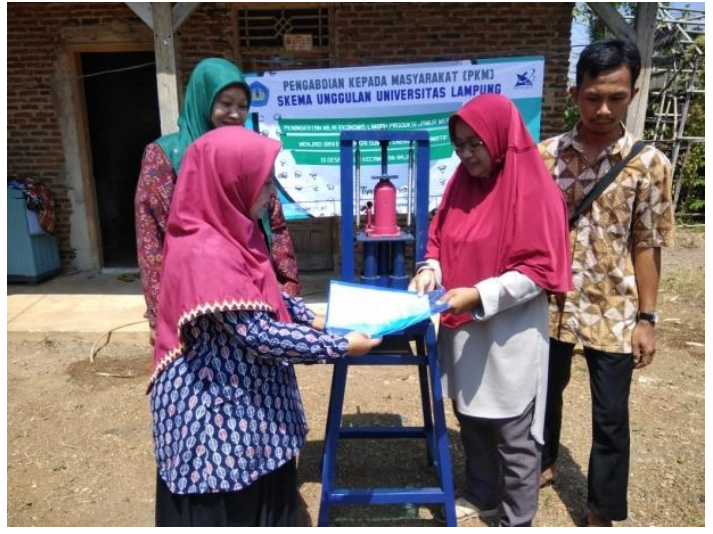

Serah terima alat dari Tim kepada Mitra

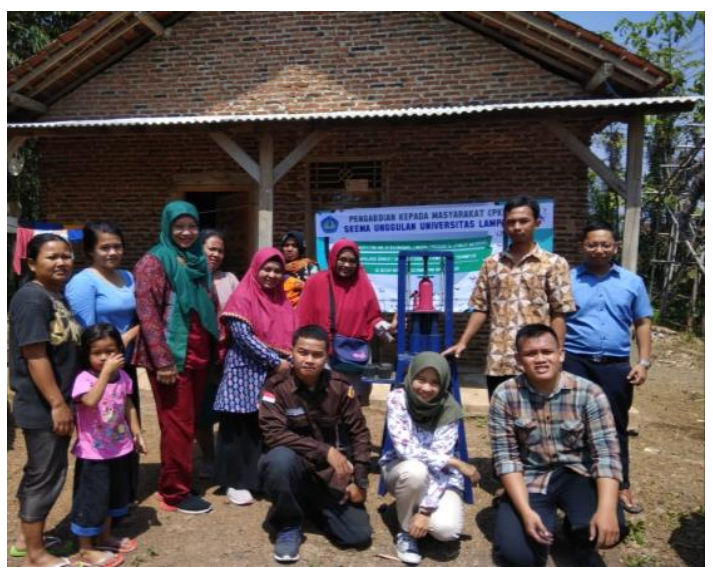

Foto bersama Tim Pelaksana Pengabdian Unila dengan Peserta Pelatihan 